\title{
Spatial targeting of ICT-based weather and agro-advisory services for climate risk management in agriculture
}

\author{
Prasun K. Gangopadhyay ${ }^{1}$ - Arun Khatri-Chhetri ${ }^{2}$ - Paresh B. Shirsath ${ }^{2}$. \\ Pramod K. Aggarwal ${ }^{2}$
}

Received: 20 September 2018 / Accepted: 19 March 2019 / Published online: 16 April 2019

(C) The Author(s) 2019

\begin{abstract}
The increasing frequency of climatic risks, such as flood, drought, heat and cold waves, is causing significant loss of farm productivity and income in agriculturally dependent communities. Timely availability of reliable information on weather conditions, agro-advisories, and market information can help to minimize losses in agriculture. This paper presents a scientific and integrated approach to identify areas of high agriculture vulnerability to climate change and availability of ICT services for dissemination of CSA information in the vulnerable areas. This study was illustrated for India where the majority of the population depends on agriculture for their livelihoods, and this sector is highly vulnerable to climate change. The study presents four regions: i) high agriculture vulnerability and low ICT services, ii) high agriculture vulnerability and high ICT services, iii) low agriculture vulnerability and low ICT services, and iv) low agriculture vulnerability and high ICT services. This methodology, which is simple, uses available data, and is easy to apply, can be useful to prioritize locations for climate-smart interventions, mode of CSA information dissemination using ICT services, and increase coverage of agro-ICT services through development of ICT services in the locations where climate change impact is high and ICT services are very low. This study also showed that there is a need to improve the quality of existing climate information and agro-advisory services in the climate risk-prone areas.
\end{abstract}

Prasun K. Gangopadhyay and Arun Khatri-Chhetri contributed equally to this work.

Electronic supplementary material The online version of this article (https://doi.org/10.1007/s10584-01902426-5) contains supplementary material, which is available to authorized users.

Prasun K. Gangopadhyay

P.Gangopadhyay@cgiar.org

Arun Khatri-Chhetri

a.khatri-chhetri@cgiar.org

1 Borlaug Institute of South Asia (BISA), International Maize and Wheat Improvement Centre (CIMMYT), New Delhi, India

2 Climate Change, Agriculture and Food Security (CCAFS), Borlaug Institute of South Asia (BISA), International Maize and Wheat Improvement Centre (CIMMYT), New Delhi, India 


\section{Introduction}

Agricultural production is often volatile due to external factors, such as weather, insect/pests, diseases, and input/output prices. Recently, increasing climatic risks in agriculture are causing serious distresses to farming communities across the world (Hansen et al. 2018; Falco et al. 2018; Knox et al. 2012). It has been well documented that agricultural production could be significantly impacted owing to increases in temperature, changes in rainfall patterns, and incidence of extreme climatic events, such as floods, droughts, and heat/cold waves (Aggarwal et al. 2018; Khatri-Chhetri et al. 2017). Furthermore, agriculture in its different forms and locations remains highly vulnerable to climatic variability, which is a major factor of interannual variation in food production (Ray et al. 2015; Howden et al. 2007). Given the impacts of climate change on agriculture, enhancing farmers' capacity to manage climatic risks can be an important adaptation strategy in agriculture and allied sector, such as processing units, livestock, fisheries, etc.

Depending upon food production systems and locations, there is a large array of adaptation and mitigation options to address climate change and variability in agriculture. Adaptation options that sustainably increase productivity, enhance resilience to climatic stresses, and reduce greenhouse gas emissions are known as climate-smart agricultural (CSA) technologies, practices, and services (FAO 2010). Broadly, CSA focuses on developing resilient food production systems that lead to food and income security under progressive climate change and variability (Vermeulen et al. 2012, Lipper et al. 2014). In many locations, change in crop and livestock management practices, use of new farm technologies, and change in land use patterns help to adapt climatic risks in agriculture. These practices include use of improved climate resilient seeds, crop nutrients and water management practices, changes in tillage practices (such as conventional to minimum tillage), change in sowing time based on climate information, etc. (Howden et al. 2007; Dunnett et al. 2018). A recent study shows farmers' preferred technologies generally depend on total annual rainfall and that the choices are largely around rainwater harvesting, crop insurance, laser leveling, and fodder management (Khatri-Chhetri and Aggarwal 2017). Similarly, many climatesmart agricultural practices can potentially reduce greenhouse gas emissions without compromising food production (Sapkota et al. 2018). However, farmers often lack access to updated information on several CSA technologies, practices, and services that are available to them in the market. Availability of timely information on weather forecasts, value-added agricultural advisories, such as climate information-based input use and crop management practices and market information, empowers farming communities in tackling climate and market risks in agriculture (Magawata 2014; Shaik et al. 2011; Singh and Meena 2012).

The use of information and communication technologies (ICTs), such as cell phones, televisions, radio, and internet services, is an emerging field for dissemination of climate-smart agriculture (CSA) technologies, practices, and services to the rural farmers. Several studies also indicate that ICT-based climate information and agro-advisory services can help farmers to make better in-season crop management decisions, choice of technology, and marketing strategy (Ospina and Heeks 2012; Kumar and Singh 2012; Mittal et al. 2010). However, reliable and economical ICT services are crucial for the dissemination of CSA information to the rural agricultural communities. In addition, the role of ICTs is not confined only to disseminate CSA information, rather it has reduced the costs of gathering, processing, and decision making along with disseminating timely information that helps farmers to mitigate climate and associated risks. For example, timely information of monsoons, which is provided by weather forecasting agencies, would help farmers to take decision to sow in the right time to cope with rainfall related uncertainties particularly in rain-fed areas (Raghuvanshi et al. 2018; Dinesh 2016). Customized agro-advisories, 
which are usually offered by service providers, often supply very detailed information for crop management to mitigate climate related agricultural risks on a case by case basis.

In developing countries particularly, where timely access to CSA information is limited by several factors, including available flow of information through reliable channels, ICT has incredible potential to improve agricultural productivity (World Bank 2017). Along with disseminated by ICT services, the CSA technologies and practices would be more accessible by farmers, particularly by small and marginal, if they are linked and promoted within the government's ongoing agriculture development programs (FAO 2017). Policies and programs that are focused on sustainable agricultural development, water conservation, crop insurance, etc., have potential to integrate CSA activities.

Targeting ICT-based climate information and agro-advisory services for climate change adaptation requires a systematic assessment of agricultural vulnerability to climate change and variability, availability of ICT services and farmers' access to them. Despite widespread recognition of the importance of ICT-based climate information and agro-services and farmers need, there is little evidence in targeting locations where agriculture is highly vulnerable to climate change and availability of ICT services are major constraints. Information about the type and coverage of ICT services in the climatic risk prone areas can help to design climate information-based agro-advisory services suitable to the local farmers (Tall et al. 2018). Some studies show that the rate of CSA adoption and food security status are high in the locations where farmers have access to the advanced climate services (McKune et al. 2018; Huysen et al. 2018). Therefore, assessing where climate information services are required and which ICT tool can be used to disseminate climate information-based agro-advisories can help in shaping future initiatives for climate risks management in agriculture.

This paper presents a scientific and integrated approach to identify areas of high agriculture vulnerability to climate change and availability of ICT services for dissemination of CSA information in the vulnerable areas. This study was conducted in India where the majority of the population depends on agriculture for their livelihoods and where this sector is highly vulnerable to climate change (Pathak et al. 2012; GoI 2018). Many studies also show that climate change could reduce a significant amount of farm income (>20\%) in the country (Burgess et al. 2014; Aggarwal 2008). The objective of the study, therefore, is to present a methodology of identification of hotspots for climatic risks in agriculture and coverage of ICT services by illustrating for India. The hotspots include locations where agriculture vulnerability to climate change is very high with limited access to ICT services. This paper presents four regions: i) high agriculture vulnerability and low ICT services, ii) high agriculture vulnerability and high ICT services, iii) low agriculture vulnerability and low ICT services, and iv) low agriculture vulnerability and high ICT services. This methodology can be used in the climatically risk prone areas for targeting broad geographical regions for dissemination of CSA information and to enhance ICT-based agro-advisory services to minimize climate change impacts on agriculture.

\section{Data and approach}

\subsection{Assessment of agriculture vulnerability to climate change}

There are many scientific studies that cover a range of agriculture vulnerability to climate change analyses in India and South Asia (Thornton and Gerber 2010; Mani et al. 2018; Lal 2019). A comprehensive analysis of agriculture vulnerability to climate change conducted by Rao et al. 
(2013) considers a wide range of bio-physical and socio-economic indicators (e.g., land use/land cover, climate data, natural disaster, e.g., flood, cyclone, drought, etc., water availability, poverty, landholding, transport network, access to market, etc. ${ }^{1}$ ) at district level. This study used a dataset provided by Rao et al. (2013).

On the basis of the relative agriculture vulnerability to climate change, all districts in India were categorized into five classes: very high, high medium, low, and very low vulnerability. Out of the 572 rural districts (Census 2001) the first 115 districts fall into the very high vulnerability category, while the next 115, 114, 114, and 114 districts fall into high, medium, low, and very low vulnerability categories, respectively. These 572 rural districts boundaries were adjusted ${ }^{2}$ with the present administrative boundary of 622 rural districts (Census 2011) without modifying the existing vulnerability classes. Subsequently, these 622 districts were taken for further analysis excluding urban districts where agriculture is very limited. The exclusion of urban districts where ICT services are very high helps to minimize errors in hotspot analysis.

\subsection{Assessment of availability of ICT services}

The growth rate of the telecommunications sector in India is significantly high and from 2011 to 2018 wireless phone service has increased from $34 \%$ to $58 \%$ in rural India (TRAI 2011, 2018). This study uses the latest available census data of India (2011) for the hotspot analysis. In the first step, the percentage of rural households that have access to radio, television, cell phone, and computer with internet was calculated for each district. In the second step, the percentage access to selected ICT services in a district was ranked compared to all the districts of India. Similarly, all four selected ICT services were ranked as per their availability compared to all districts of India and mean of the four ranks were taken as the composite rank of access to ICT services for a district. In the third step, this relative rank of access to ICT services was classified in five classes equally: very low, low, moderate, high, and very high with cutoff relative rank values of $125,250,375$, and 500 for further analysis.

\subsection{Assessment of scope of ICT services in climate change adaption}

A hotspot analysis was conducted by overlying agricultural vulnerability (very high, high, medium, low, and very low) to climate change with access to ICT services (very high, high, medium, low, and very low) using geographic information systems (GIS). This provides a spatial relationship between the degree of agriculture vulnerabilities and access to ICT services at district level. At district level, a particular climatic risk and presence of ICT services were taken into account to explore the different scenarios and opportunities of using ICT existing services to promote CSA technologies and services, including land use planning and watershed management. Furthermore, mode of ICT services in the very highly and highly vulnerable rural districts were analyzed on the basis of the number of users in the districts. For better understanding, the very high to high vulnerability districts were combined together as 'high' category and the medium to very low vulnerability districts were combined as 'low' category. This study also uses rural income poverty level (\% of population under poverty line)

\footnotetext{
${ }^{1}$ Details of indicators are presented as Annexure 1

${ }^{2}$ With the growth of population many of the districts of India are bifurcated in two or more for ease of governance. In this study we have used the latest available district boundary data and assigned the same vulnerability class of the previous district for all the new bifurcated districts.
} 
at the district level to identify people's purchasing power of ICT services. Districts were identified as the hotspots where agriculture vulnerability to climate change is high, access to ICT services is low, and poverty level is high. Finally, we estimated cost of climate information and agro-advisory service provision through cell phone to the hotspot areas. Current service charge per farmer per season was used to calculate cost of cell phone-based agro-advisories. This cost was obtained through the survey of current ICT-based climate information and agro-advisory providers in different locations of India. Figure 1 presents a systematic methodology of a hotspot analysis used in this study.

\subsection{Assessment of farmers' access to current ICT services}

A household survey was conducted to identify farmers' access to different sources of ICT services, reliability of information received, and usefulness of weather information and agro-advisory services in agricultural management decision making. This survey was conducted in 2017-2018 with 2671 randomly selected farmers in five randomly selected climatically highly vulnerable states (Bihar, Madhya Pradesh, Maharashtra, Rajasthan and Uttar Pradesh) and 12 hotspot districts in the states. Farmers were asked about the reliability and usefulness of four major sources of ICT services (cell phone, television, radio, and internet). For reliability, this study used a five-

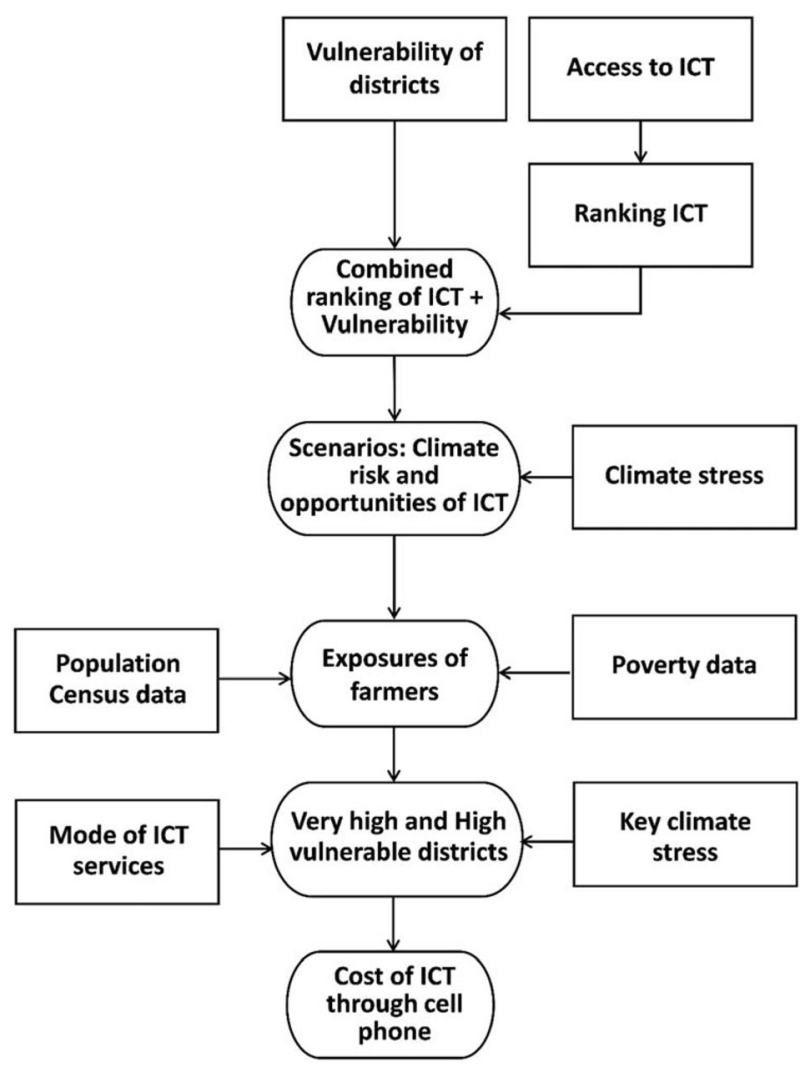

Fig. 1 Flowchart of methodology: assessment of agriculture vulnerability and ICT services 
point Likert scale, where $1=$ unreliable, $2=$ somewhat reliable, $3=$ fairly reliable, $4=$ very reliable, and $5=$ fully reliable. Similarly, the five-point Likert scale for usefulness includes, $1=$ not useful, 2 = somewhat useful, 3 = fairly useful, $4=$ very useful, and $5=$ fully useful.

\section{Results}

\subsection{Access to ICT services in climate change vulnerable districts}

Agriculture vulnerability assessment results show that out of 622 districts, 124 fall into very highly vulnerable in 15 states, while 122 are in highly vulnerable categories in 19 states of India (Fig. 2). In these districts, $30.3 \%$ and $23.5 \%$ of India's (rural districts) farmers live in very highly and highly vulnerable zones, respectively. The highly vulnerable to climate change districts constitute more than $50 \%$ of India's farmer population. Among the highly vulnerable states of India, Rajasthan has the maximum number of farmers $(10.3 \%)$ followed by Maharashtra (7.2\%), Uttar Pradesh (7\%), and Madhya Pradesh (6.3\%).

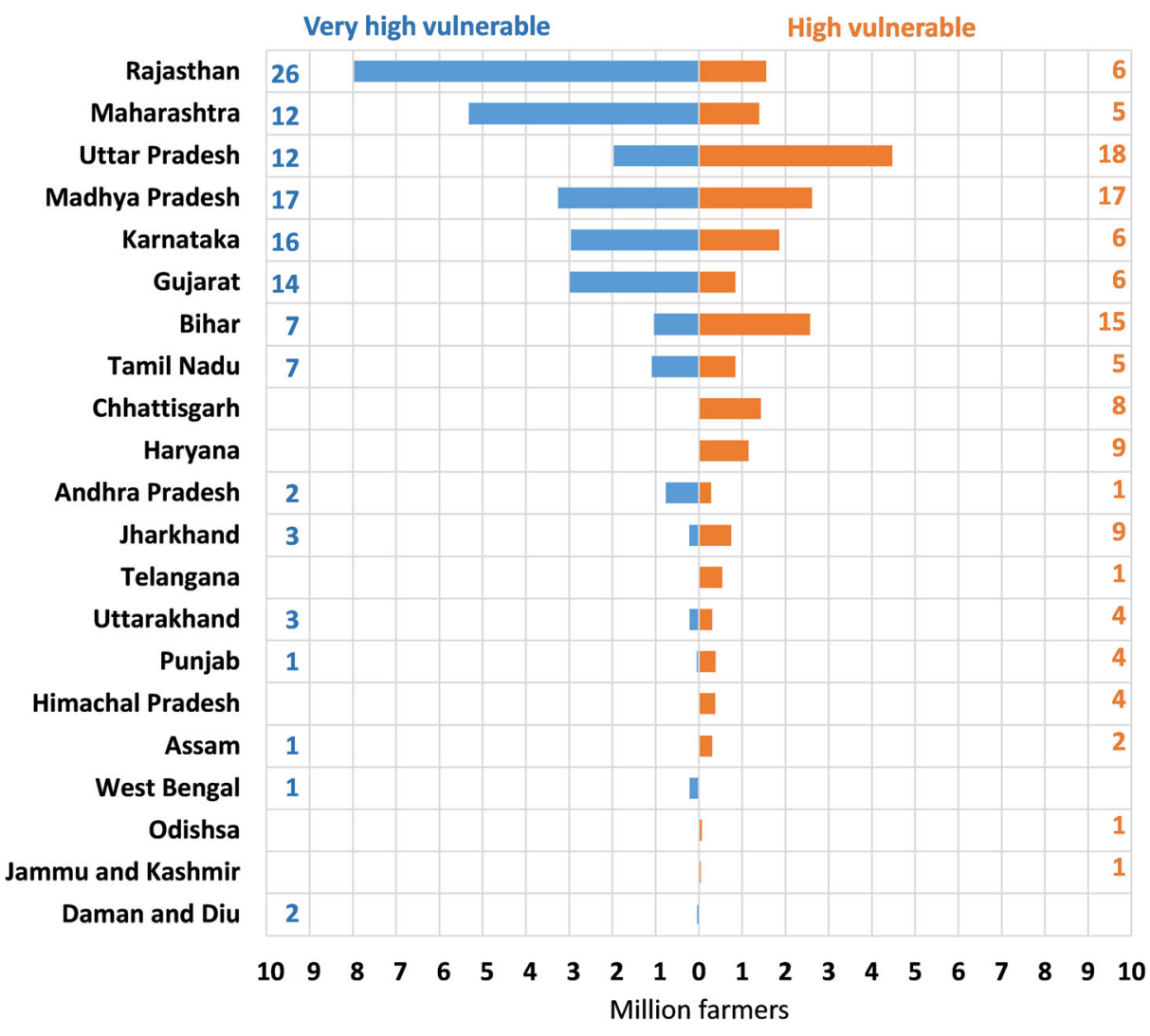

Fig. 2 Number of districts and farmers in very highly and highly vulnerable states of India. The $\mathrm{x}$-axis value represents number of farmers in million and y-axis values represents number of districts in very highly (blue color) and highly (orange color) vulnerable classes 
In India, out of 179 million rural households, $47.5 \%$ has access to cell phones, while $35.4 \%$, $19.2 \%$, and $0.8 \%$ have ownership of television, radio, and computer with internet access, respectively. Data shows that the majority of the districts in all rural districts in central India lack ICT services and fall into the very low to low access to ICT services category (Fig. 3). In 447 districts in India, where cell phones are a primary source of ICT service, covers more than $80 \%$ of farmers (primary occupation is cultivator). Out of these 447 districts, 246 fall under high climate vulnerability categories. Coverage of ICT services such as television and radio were in second and third rank in the districts.

\subsection{Hotspots for ICT services}

Figure 4 presents hotspots of agriculture vulnerability to climate change and access to ICT service across India. All rural districts were categorized into four groups based on the combination of agriculture vulnerability to climate change and access to ICT services. High vulnerability and low access to ICT services (category 1) includes 114 districts. Similarly, high vulnerability with high ICT access (category 2), low vulnerability and high ICT access (category 3) and low vulnerability and low ICT access (category 4) include 132, 240, and 136 districts respectively. Similarly, large number of farmers are in high vulnerability and high access to ICT services (27.7 million), followed by low vulnerability and high access to ICT services 25.1 million), high vulnerability and low access to ICT services (22.1 million) and low vulnerability and low access to ICT services (17.6 million).

Table 1 presents a number of districts and farmers in the hotspot districts in highly vulnerable states of India. A large number of hotspot districts with high vulnerability and low access to ICT services are located in Madhya Pradesh, Maharashtra, Rajasthan, Jharkhand,

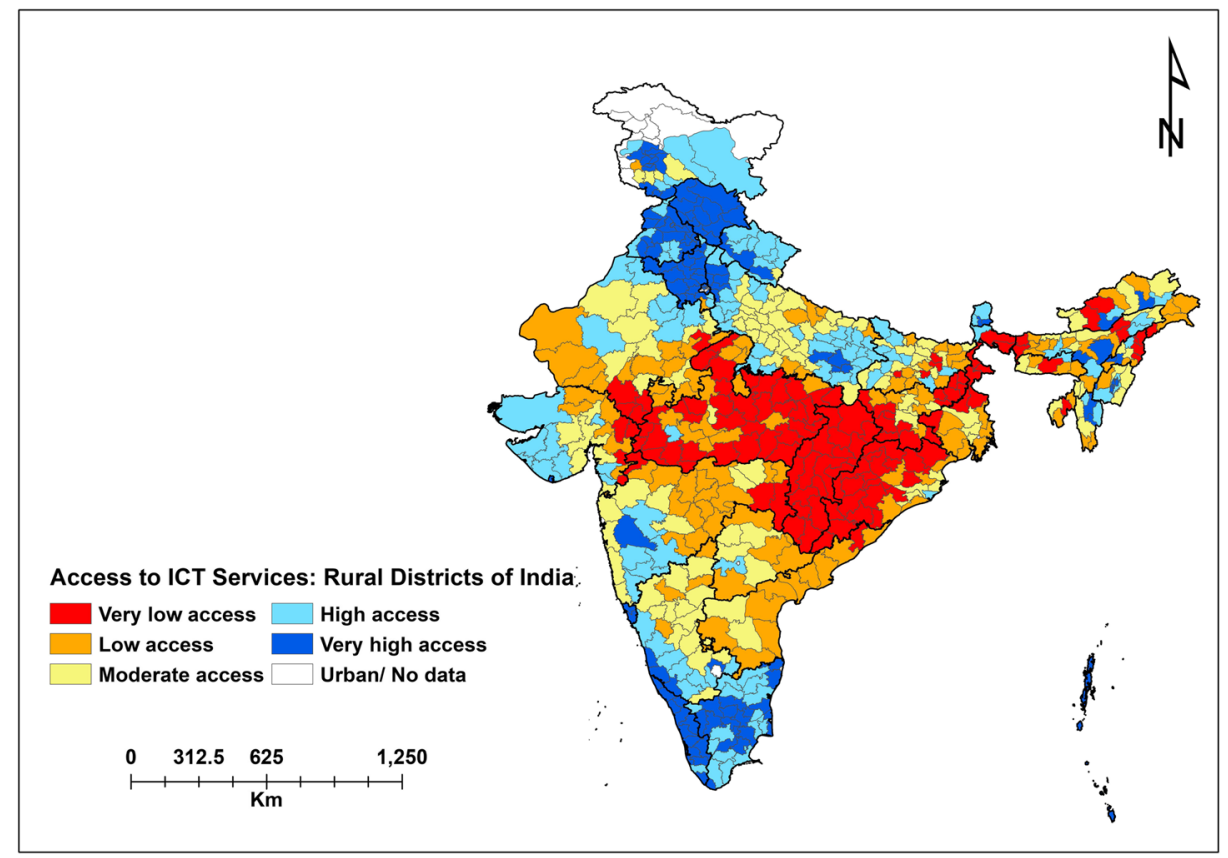

Fig. 3 Relative ranking of access to ICT services in the rural districts of India 


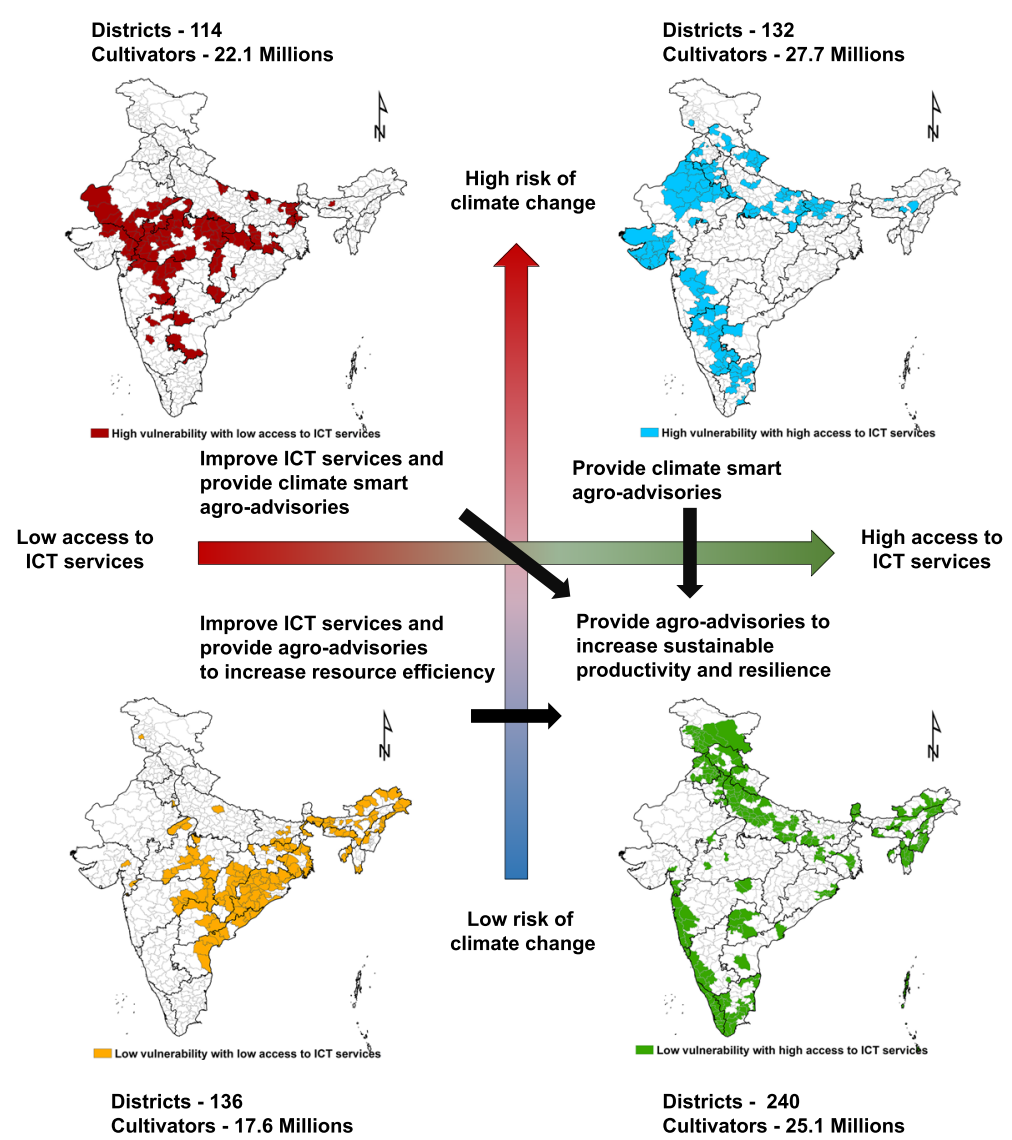

Fig. 4 The four scenarios of climate change related risk and opportunities of ICT services

Gujarat, and Bihar where the majority of the population depends on agricultural activities for their livelihoods.

Districts that are low vulnerability and have comparatively lower access to ICT services are mostly concentrated in the states of Odisha and Madhya Pradesh. The 240 districts with low vulnerability and high access to ICT services are primarily in Uttar Pradesh, Jammu and Kashmir, Tamil Nadu, Punjab, and spread over in the other 26 states. The districts that are having better access to ICT services in the high vulnerability areas have more access to cell phones.

\subsection{Climatic risks and ICT services in hotspots}

This study has analyzed the major climatic risks in the hotspot areas across India. Three major climatic risks: uncertainty in rainfall, drought probability, and increase in temperature (minimum and maximum) are mapped in Fig. 5. There are several other factors like flood or saltwater intrusion which are also important in this context; however, due to lack of data on regionspecific future climatic variability, we restricted our analysis to only rainfall and temperature related uncertainties. July rainfall, which is a deciding factor for production of Kharif (monsoon) crops, is projected to decrease in 74 hotspot districts, mainly in Bihar, Rajasthan, Tamil Nadu, and Karnataka (Revadekar and Preethi 2011; Venkatraman 2014). 
Table 1 Districts with high agriculture vulnerability and low ICT access in India

\begin{tabular}{|c|c|c|c|c|}
\hline \multirow[t]{2}{*}{ State } & \multicolumn{2}{|c|}{$\begin{array}{l}\text { High vulnerability and medium } \\
\text { access to ICT services }\end{array}$} & \multicolumn{2}{|c|}{$\begin{array}{l}\text { High vulnerability and low } \\
\text { access to ICT services }\end{array}$} \\
\hline & No. of districts & $\begin{array}{l}\text { No. of farmers ( } \% \\
\text { of total farmer) }\end{array}$ & No. of districts & $\begin{array}{l}\text { No. of farmers } \\
\text { (\% of total farmer) }\end{array}$ \\
\hline Andhra Pradesh & 1 & $285,374(0.21)$ & 2 & $763,830(0.82)$ \\
\hline Assam & 2 & $141,873(0.15)$ & 1 & $183,880(0.20)$ \\
\hline Bihar & 14 & $2,483,181(2.68)$ & 8 & $1,125,792(1.21)$ \\
\hline Chhattisgarh & & & 8 & $1,434,463(1.55)$ \\
\hline Daman and Diu & 2 & $1053(0.001)$ & & \\
\hline Gujarat & 12 & $1,911,425(2.06)$ & 8 & $1,915,752(2.07)$ \\
\hline Jharkhand & & & 12 & $971,909(0.05)$ \\
\hline Haryana & 9 & $1,149,011(1.24)$ & & \\
\hline Himachal Pradesh & 4 & $378,797(0.41)$ & & \\
\hline Jammu and Kashmir & 1 & $42,658(0.05)$ & & \\
\hline Karnataka & 18 & $4,181,623(4.51)$ & 4 & $635,395(0.69)$ \\
\hline Madhya Pradesh & & & 34 & $5,870,435(6.33)$ \\
\hline Maharashtra & 6 & $3,923,816(4.23)$ & 11 & $2,789,416(3.01)$ \\
\hline Odisha & & & 1 & $70,791(0.08)$ \\
\hline Punjab & 5 & $433,864(0.47(0.47)$ & & \\
\hline Rajasthan & 15 & $5,347,230(5.77)$ & 17 & $4,180,092(4.51)$ \\
\hline Telangana & & & 1 & $539,503(0.58)$ \\
\hline Tamil Nadu & 12 & $1,929,891(2.08)$ & & \\
\hline Uttar Pradesh & 24 & $4,954,026(5.34)$ & 6 & $1,491,812(1.61)$ \\
\hline Uttarakhand & 7 & $525,058(0.57)$ & & \\
\hline West Bengal & & & 1 & $216,420(0.23)$ \\
\hline Total & 132 & $27,688,880(29.86)$ & 144 & $22,189,490(23.93)$ \\
\hline
\end{tabular}

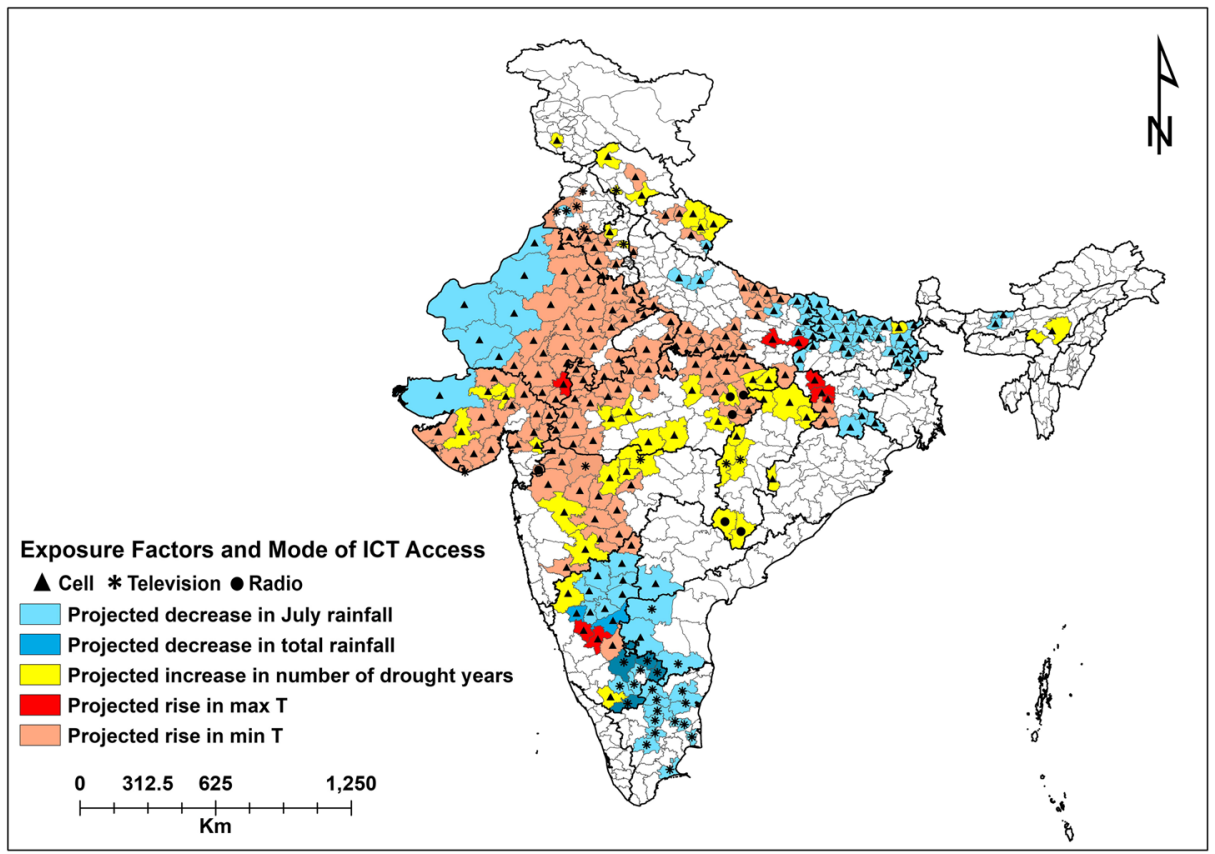

Fig. 5 Mode of ICT services in the very highly and highly vulnerable districts 
CSA information about weather-based crop advisories, water management, and drought resistant crops, including crop insurance, can help millions of farmers to minimize drought related climatic risks. About 118 hotspot districts will experience an increase in minimum/maximum temperatures, mainly in Rajasthan, Maharashtra, Gujrat, and Uttar Pradesh. Promotion of CSA technologies and practices such as stress tolerant verities, water conservation practices, and pest/disease control, related to agro-advisories can help to minimize temperature change related stresses. To identify the preferred mode of ICT access to deliver climate information-based agroadvisories, spatial correlation analysis was done between climate risks and preferred mode of ICT (Fig. 5). Results show that access to mobile phone is relatively high in these hotspot districts compared to other ICT services.

\subsection{Farmers' access to ICT services in the hotspots}

This study assessed farmers' access to ICT-based weather information and agro-advisory services in 12 hotspot districts in five states (Bihar, Madhya Pradesh, Maharashtra, Rajasthan, and Utter Pradesh) of India. Figure 6 presents farmers' response on access to ICT-based climate information and agro-advisory services, reliability and usefulness of the information. In many hotspot districts, farmers' current access to ICT-based weather information and agroadvisory services was very low. Among the ICTs, television and cell phone were major sources of weather and agro-advisory services. Results also show that reliability of currently available weather information and agro-advisory services were low. A very limited number of farmers believed that current ICT-based information services were useful for making better management decisions in agriculture.
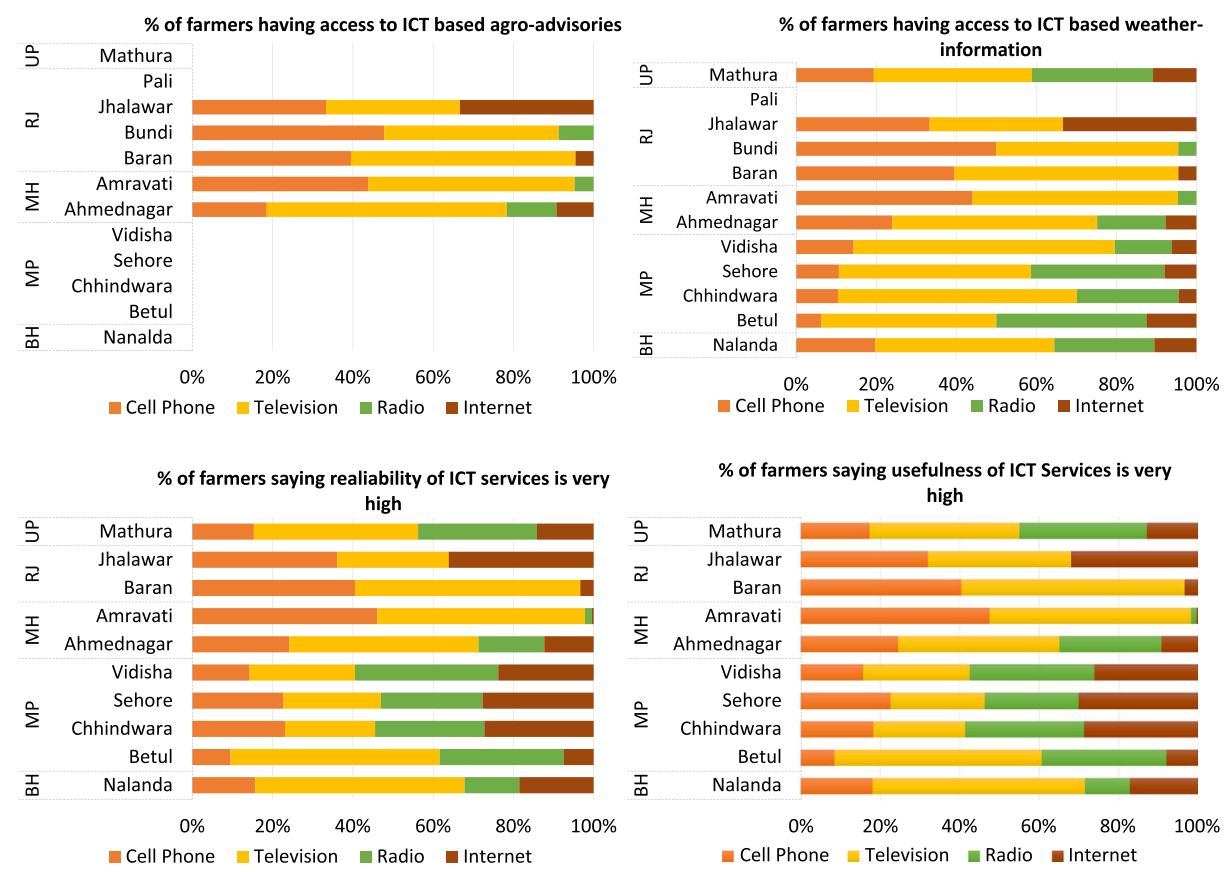

Fig. 6 Farmers' access to ICT services in the selected districts in vulnerable zones of India 


\section{Discussion}

Reduction of agriculture vulnerability to climate change is one of the major objectives in agriculture sector development. Therefore, provision of climate information and agro-advisory services depends on the hotspot categories. In areas where vulnerability to climate change is high with low access to ITC services (category 1), the first priority should be to increase access to ICT services through development of ICT infrastructure and supply of ICT services. The second step should focus on provision of ICT-based climate information and agro-advisory services based on agricultural production systems in the areas. In high vulnerability and high access to ICT services areas (category 2), focus should be on developing climate information-based agroadvisories and providing it via the most covered ICT services, such as cell phone, television, and radio. Low vulnerability to climate change and low access to ICT services areas (category 4) may also need improvement in access to ICT services to promote new agricultural technologies and practices with less focus on climate risks management. For farmers located in the best case scenario (low vulnerability to climate change and high access to ICT services), the provision of ICT-based climate information and agro-advisory services can help them to manage agricultural inputs (water, seed, fertilizer, and energy) in better ways to get maximum benefit of good climatic conditions.

\subsection{Cost of ICT services provisions in the hotspots}

This study estimated the cost of climate information and agro-advisory services in the hotspot districts and use of climate information and agro-advisories. These cost calculations are not only useful for state level ministries of agriculture but also private ICT service providers who provide climate information and agro-advisory services, agriculture insurance companies who provide information about agriculture insurance schemes, agriculture input suppliers who can provide information about available technologies, and so on. Current average cost of climate information-based agroadvisory services was US\$ 2.5 per farmer per cropping season, which include information about weather forecasts, sowing dates, water and nutrient efficient management practices, crop residue management, disease and pest control, market prices and trends, and relevant government schemes. The total estimated cost is US\$ 62.5 million for ICT-based agro-advisory services in the highly vulnerable districts, where cell phone is the primary choice to access information. Figure 7 presents an estimated cost of cell phone-based ICT services in the hotspot districts across India. Total cost per district ranges from $<1$ million to 2.3 million US\$. This cost of ICT services was mapped with current level poverty in the hotspot districts. Many hotspot districts in Northern India (Bihar and Uttar Pradesh) include a large number of poor farmers, who have low purchasing power of ICT services as well as ICT-based agro-advisory services. The dissemination of ICT-based climate information and agro-advisory services in these areas may need large government supports. The estimated cost of ICT services for nine districts that are very highly vulnerable with high poverty and better ICT access is US\$ 3.25 million/cropping season for cell phone-based advisories. For 56 districts that are highly vulnerable districts with high poverty the cost is US\$ $33.69 \mathrm{million} / \mathrm{cropping}$ season. 


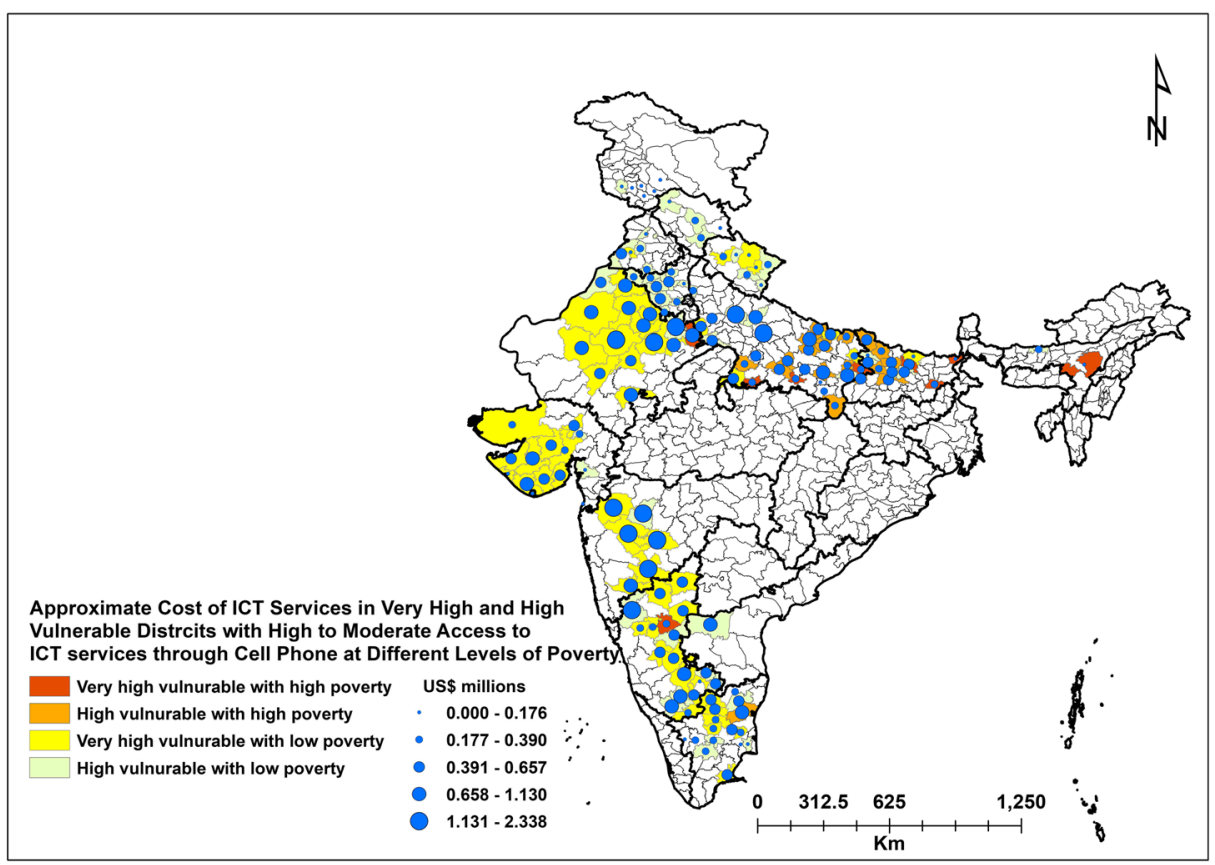

Fig. 7 Estimated cost of ICT services through cell phone per season

\subsection{Improving farmers' access to ICT services}

This study observed that a large number of farmers lack access to reliable ICT services in many climatically vulnerable districts across India. This study shows that cell phone coverage is highest followed by television and radio. Farmers' access to cell phones has also been rapidly increasing recently. Development and supply of cell phone-based climate information and agro-advisory services can cover a large area of farming communities across the India. This ICT service can encourage local farmers to form a group in social media to share experiences, including new technologies, practices, and market information. Apart from traditional methods where government or service provider acts as a knowledge provider, farmers' groups can exchange information through smartphones and benefit mutually without any external support.

Apart from cell phone-based agro-advisories, mass media, such as television and radio, could be used effectively to provide weather information and agro-advisory services to the farmers (Purushothaman et al. 2003; World Bank 2017; Ajayi 2019). Using success stories of local farmers who have adopted CSA technologies and experienced significant benefit would be encouraging to farmers' communities. In very remote areas, where farmers' communities do not have much access to cell phone networks or cannot afford television, provision of weather information and agro-advisory services through radios would be very effective. This service can include information on CSA technologies and practices, farmers' success stories, and market information and links. 


\subsection{Development of value-added agro-advisory services}

Recent advancement in agricultural knowledge, communication technologies, and the ability to analyze a large database can help to generate more customized weather information-based agro-advisory services to the farmers. However, current agro-advisory services lack the use of such information and technologies to generate context-specific agro-advisory services. Artificial intelligence (AI)-based agro-advisory systems are well established in many developed countries (Umadikar et al. 2014; ICRISAT 2018; Reddy et al. 2018).

A two-way information flow model can be highly useful to address more localized climate risks and agriculture production related farmers' problems. Figure 8 presents a basic structure of the prototype for two-way information flow to improve the existing weather information and agro-advisory service system. The prototype consists of an artificial intelligence (AI)enabled server with the capabilities to recognize and extract information from input image and text to provide advisories, database from field (crop, management practices, etc.) through mobile app, database from agencies (weather, efficient technologies, etc.) verified by a panel of experts, input from remote sensing sensors, field scouts/progressive farmers, and enrolled beneficiaries.

Conceptually, the server collects data from the field through mobile apps to create profiles of farmers to provide customized advisories throughout the lifecycle of the crop under consideration. A combination of different methods can help to collect crop management practices, monitor crop health, insect/pest and disease outbreaks through image recognition system. On the basis of the information that is provided from the field to the server, an AIbased system analyzes the inputs and generates advisories based on the provided information. Systematically, the process is being monitored by the panel of experts for quality control and upgradation for better decision making. In due course, a larger area, including the present study area, will be monitored with the inputs from sensors onboard satellites/UAV/drones for early warning of any disease or insect/pest outbreak.

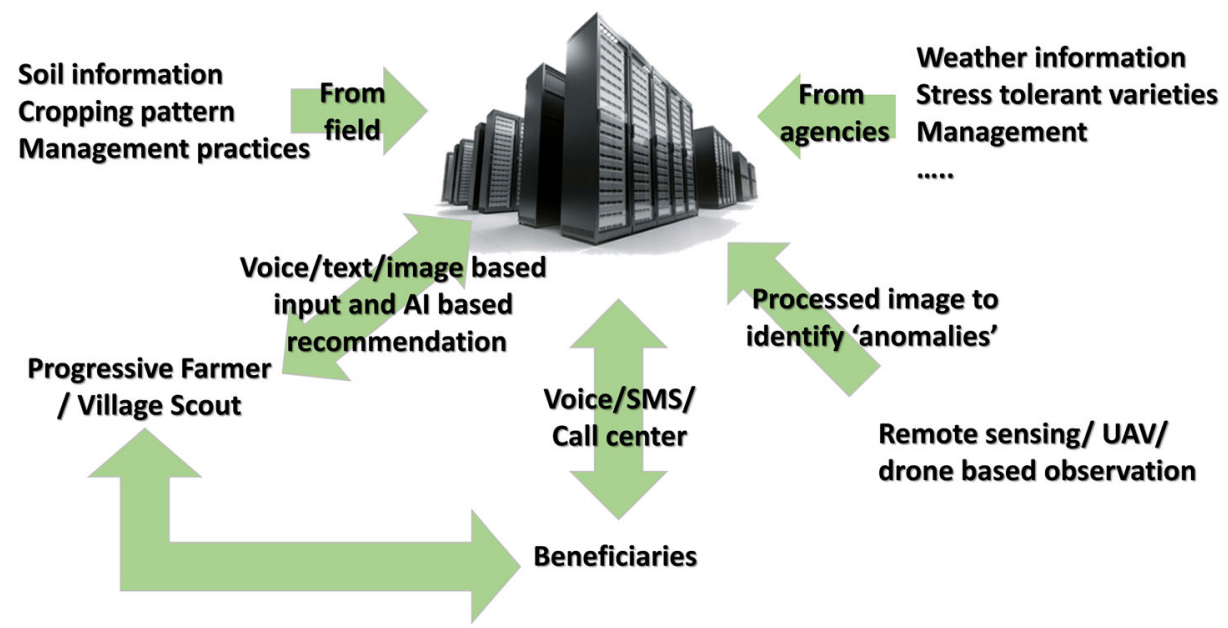

Fig. 8 Basic structure of the prototype for two-way information flow 


\section{Conclusion}

Addressing climate change impacts on agriculture is a special challenge that needs efficient channeling of resources and information to strengthen farmers adaptive capacity to climate change and variability. Many climate change adaptation and mitigation related policies and programs focus on implementation of climate-smart practices, technologies, and services to cover large agricultural areas and populations. This study presents a methodology to highlight/ target broad geographical regions for designing and implementing ICT-based climate information and agro-advisory services. This methodology — which is simple, uses available data, and is easy to apply - can be useful to prioritize locations for climate-smart interventions, mode of CSA information dissemination using ICT services, and increase coverage of agroICT services through development of ICT services in the locations where climate change impact is high and ICT services are very low. This study also showed that there is a need to improve the quality of existing climate information and agro-advisory services in many locations. Similarly, use of particular types of ICT services and coverage can play a crucial role while prioritizing dissemination of climate information and agro-advisory services in the targeted locations and population. This analysis needs to be followed by further examination of the socio-economic characteristics of agriculture dependent communities to design suitable climate information and agro-advisory services and ICT for disseminating them.

Acknowledgements The authors acknowledge the intellectual inputs from Prof. Arun K Joshi, Asia Regional Representative, CIMMYT and critical comments by anonymous reviewers that have helped to improve this paper. This work was implemented as part of the CGIAR Research Program on Climate Change, Agriculture and Food Security (CCAFS), which is carried out with support from the CGIAR Trust Fund and through bilateral funding agreements. For details please visit https://ccafs.cgiar.org/donors. The views expressed in this document cannot be taken to reflect the official opinions of these organizations.

Open Access This article is distributed under the terms of the Creative Commons Attribution 4.0 International License (http://creativecommons.org/licenses/by/4.0/), which permits unrestricted use, distribution, and reproduction in any medium, provided you give appropriate credit to the original author(s) and the source, provide a link to the Creative Commons license, and indicate if changes were made.

\section{References}

Aggarwal PK (2008) Global climate change and Indian agriculture: impacts, adaptation and mitigation. Indian J Agric Sci 78(11):911-919

Aggarwal PK, Jarvis BMC, Zougmoré RB, Khatri-Chhetri A, Vermeulen SJ, Loboguerrero A, Sebastian LS, Kinyangi J, Bonilla-Findji O, Radeny M, Recha J, Martinez-Baron D, Ramirez-Villegas J, Huyer S, Thornton P, Wollenberg E, Hansen J, Alvarez-Toro P, Aguilar-Ariza A, Arango-Londoño D, Patiño-Bravo V, Rivera O, Ouedraogo M, Tan Yen B (2018) The climate-smart village approach: framework of an integrative strategy for scaling up adaptation options in agriculture. Ecol Soc 23(1):14. https://doi. org/10.5751/ES-09844-230114

Ajayi O (2019) Enhancing the resilience of smallholder farmers to climate change: the scaling-up project in Southern Africa. Presented at the CTA Workshop on catalysing actionable knowledge to implement climate-smart solutions for next-generation ACP agriculture, 22-25 January, Wageningen, Netherlands

Burgess R, Deschenes O, Donalson D, Greenstone M (2014) The unequal effects of weather and climate change: evidence from mortality in India. Working Paper, MIT. Available at: http://econ.lse.ac. uk/staff/rburgess/wp/WD_master_140516_v3.pdf (Retrieved on 2 Feb 2019)

Census India (2001) Ministry of Home Affairs, Government of India. Retrieved on 10 May 2018 from http:/censusindia.gov.in/ 
Census India (2011) Ministry of Home Affairs, Government of India. Retrieved on 10 May 2018 from http://censusindia.gov.in/

Dinesh D (2016) Agricultural practices and technologies to enhance food security, resilience and productivity in a sustainable manner: messages for SBSTA 44 agriculture workshops. CCAFS Working Paper no. 146. Copenhagen, Denmark: CGIAR Research Program on Climate Change, Agriculture and Food Security (CCAFS). Available online at: www.ccafs.cgiar.org (Retrieved on 2 Feb 2019)

Dunnett A, Shirsath PB, Aggarwal PK, Thornton P, Joshi PK, Pal BD, Khatri-Chhetri A, Gosh J (2018) Multiobjective land use allocation modelling for prioritizing climate-smart agricultural interventions. Ecol Model 38(11):23-35. https://doi.org/10.1016/j.ecolmodel.2018.04.008

Falco C, Donzelli F, Olper A (2018) Climate change, agriculture and migration: a survey. Sustainability 10:1405. https://doi.org/10.3390/su10051405

FAO (2010) Climate smart agriculture: policies, practices and financing for food security, adaptation and mitigation. Food and Agriculture Organization of the United Nations (FAO), Rome

FAO (2017) Information and communication technology (ICT) in agriculture: a report to the G20 agricultural Deputies. Food and Agriculture Organization of the United Nations (FAO), Italy, Rome. http://www.fao. org/3/a-i7961e.pdf (Retrieved on Feb 2, 2019)

GoI (2018) Economic Survey of India 2017-18. Government of India. Available at: http://www. indiaenvironmentportal.org.in/files/file/economic\%20survey\%202017-18\%20-\%20vol.1.pdf (Retrieved on 2 Feb 2019)

Hansen J, Hellin J, Rosenstock T, Fisher E, Cairns J, Stirling C, Lamanna C, van Etten J, Rose A, Campbell B (2018) Climate risks management and rural poverty reduction. Agric Syst (in press). https://doi.org/10.1016 /j.agsy.2018.01.019

Howden SM, Soussana J, Tubiello FN, Chhetri N, Dunlop M, Meinke H (2007) Adapting agriculture to climate change. PNAS 104 (50): 19691-19696. https://doi.org/10.1073/pnas.0701890104

Huysen T, Hansen J, Tall A (2018) Scaling up climate services for smallholder farmers: learning from practice. Climate Risk Management 22:1-3. https://doi.org/10.1016/j.crm.2018.10.002

ICRISAT (2018) Digital agriculture: pathway to prosperity. http://www.icrisat.org/digital-agriculture/ (Retrieved on 09 January 9, 2019)

Khatri-Chhetri A, Aggarwal PK (2017) Adapting agriculture to changing climate in South Asia. World Agriculture, http://www.world-agriculture.net/article/adapting-agriculture-to-changing-climate-in-south-asia-1

Khatri-Chhetri A, Aggarwal PK, Joshi PK, Vyas C (2017) Farmers' prioritization of climate-smart agriculture (CSA) technologies. Agric Syst 151:84-191. https://doi.org/10.1016/j.agsy.2016.10.005

Knox J, Hess T, Daccache A, Wheeler T (2012) Climate change impacts on crop productivity in Africa and South Asia. Environ Res Lett 7(3):1-8. https://doi.org/10.1088/1748-9326/7/3/034032

Kumar A, Singh KM (2012) Role of ICTs in rural development with reference to changing climatic conditions. In: Singh KM, Meena MS (eds) ICT for agricultural development under changing climate. Narenda, New Delhi

Lal R (2019) Adaptation and Mitigation of Climate Change by Improving Agriculture in India. In: Sheraz Mahdi S (ed) Climate Change and Agriculture in India: Impact and Adaptation. Springer, Cham, pp 217-227. https://doi.org/10.1007/978-3-319-90086-5 17

Lipper L, Thornton P, Campbell BM, Torquebiau EF (2014) Climate-smart agriculture for food security. Nat Clim Chang 4(2014):1068-1072

Magawata D (2014) Information and communication technology: a variable tool for mitigating climate change and improving crop production. Int Lett Nat Sci 18:53-62. https://doi.org/10.18052/www.scipress. com/ILNS.18.53

Mani M, Bandyopadhyay S, Chonabayashi S, Markandya A, Mosier T (2018) South Asia's hotspots: the impact of temperature and precipitation changes on living standards. South Asia Development Matters. World Bank, Washington, DC. https://openknowledge.worldbank.org/handle/10986/28723. (Retrieved on 09 January 9, 2019)

McKune S, Poulsen L, Russo S, Devereux T, Faas S, McOmber C, Ryley T (2018) Reaching the end goal: do interventions to improve climate information services lead to greater food security? Climate Risk Management 22:22-41. https://doi.org/10.1016/j.crm.2018.08.002

Mittal S, Gandhi S, Tripathi G (2010) Socio-economic impact of mobile phones on Indian agriculture. Working Paper No. 246, Indian Council for Research on International Economic Relations, New Delhi. http://www. icrier.org/pdf/WorkingPaper246.pdf (Retrieved on 10 May 2018)

Ospina AV, Heeks R (2012) ICT-enabled response to climate change in rural agricultural communities. Strategy brief 2, Centre for Development Informatics, University of Manchester, Manchester

Pathak H, Aggarwal PK, Singh SD (2012) Climate change impact, adaptation and mitigation in agriculture: methodology for assessment and adaptation. Indian Agricultural Research Institute (IARI), New Delhi

Purushothaman C, Kavaskar M, Reddy YA, Kanagasabapathi K (2003) Role of mass media in agriculture. International conference on communication for development in the information age: extending the benefits of technology for all. In: Jirli B, Diapk De K. Ghadei, Kendadmath GC (eds). Department of Extension 
Education, Institute of Agricultural Sciences, Banaras Hindu University, Varanasi, (India). https://www. researchgate.net/publication/319535196_ROLE_OF_MASS_MEDIA_IN_AGRICULTURE. (Retrieved on 09 Jan 2019)

Raghuvanshi R, Raj S, Bhattacharjee S (2018) Climate smart agriculture and advisory services: approaches and implications for future. Discussion Paper 1, Center for Agricultural Extension Innovations, Reforms and Agripreneurship (CAEIRA), Rajendranagar, Hyderabad

Rama Rao CA, Raju BMK, Subba Rao AVM, Rao KV, Rao VUM, Ramachandran K, Venkateswarlu B Sikka AK (2013) Atlas on vulnerability of Indian agriculture to climate change. Central Research Institute for Dryland Agriculture, Hyderabad, p 116. http://www.nicra-icar.in/nicrarevised/images/publications/Vulerability_Atlas_ web.pdf. (Retrieved on 10 May 2018)

Ray DK, Gerber JS, MacDonald GK, West PC (2015) Climate variation explains a third of global crop yield variability. Nat Commun. https://doi.org/10.1038/ncomms6989

Reddy NH, Ravi Kumar E, Reddy VM, Reddy KLR, Valli SG (2018) Bioinformatics and image processingdetection of plant diseases. In: Bapi R, Rao K, Prasad M (eds) First international conference on artificial intelligence and cognitive computing. Advances in intelligent systems and computing, vol 815. Springer, Singapore

Revadekar JV, Preethi B (2011) Statistical analysis of the relationship between summer monsoon precipitation extremes and foodgrain yield over India. Int J Climatol 32(3):419-429. https://doi.org/10.1002/joc.2282

Sapkota TB, Vetter SH, Jat ML, Sirohi S, Shirsath PB, Singh R, Jat HS, Smith P, Hiller J, Stirling CM (2018) Cost-effective opportunities for climate change mitigation in Indian agriculture. Sci Total Environ 655:13421354. https://doi.org/10.1016/j.scitotenv.2018.11.225

Shaik N, Balaji V, Muthuraman P, Sailaja B, Dixit S (2011) Changing roles of agricultural extension: harnessing information and communication technology (ICT) for adapting to stresses envisaged under climate change. In: Venkateswarlu B, Shanker AK, Shanker C, Maheswari M (eds) Crop stress and its management: perspectives and strategies. Springer, New York, pp 585-605

Singh KM, Meena MS (2012) ICTs for agricultural development under changing climate. Narenda, New Delhi

Tall A, Coulibaly JY, Diop M (2018) Do climate services make a difference? A review of evaluation methodologies and practices to access the value of climate information services for farmers: implications for Africa. Climate Services 11:1-12. https://doi.org/10.1016/j.cliser.2018.06.001

Thornton PK, Gerber PJ (2010) Climate change and the growth of the livestock sector in developing countries. Mitig Adapt Strateg Glob Chang 15(2):169-184. https://doi.org/10.1007/s11027-009-9210-9

TRAI (2011) Information Note to the Press (Press Release No. 57/2011). https://main.trai.gov. in/sites/default/files/Press_Release_Oct-11.pdf. (Retrieved on 04 June 2018)

TRAI (2018) Highlights of Telecom Subscription Data as on 31st March, 2018. http://trai.gov. in/sites/default/files/PRNo56Eng23052018.pdf. (Retrieved on 04 June 2018)

Umadikar J, Sangeetha U, Kalpana M, Soundarapandian M Prashant S Jhunjhunwala A (2014) mASK: A functioning personalized ICT-based agriculture advisory system: implementation, impact and new potential, 2014 IEEE region 10 humanitarian technology conference (R10 HTC), Chennai, pp 121-126. https://doi. org/10.1109/R10-HTC.2014.7026313

Venkatraman P (2014) Impact of monsoon rainfall on the total food grain yield over India. J Earth Syst Sci 123(5):1129-1145. https://doi.org/10.1007/s12040-014-0444-x

Vermeulen, S.J., Campbell, B.M., J.S.I. Ingram. 2012. Climate change and food systems

World Bank (2017) ICT in agriculture: connecting smallholders to knowledge, networks, and institutions, updated edn. World Bank, Washington, DC. https://doi.org/10.1596/978-1-4648-1002-2

Publisher's note Springer Nature remains neutral with regard to jurisdictional claims in published maps and institutional affiliations. 